\title{
CORRECTION
}

Fuat Usta • Hüseyin Budak • Tuba Tunç •

Mehmet Zeki Sarikaya

\section{Correction to: New bounds for the Ostrowski-type inequalities via conformable fractional calculus}

Published online: 21 March 2018

(C) The Author(s) 2018

\author{
Correction to: Arab. J. Math. \\ https://doi.org/10.1007/s40065-018-0201-0
}

Unfortunately, the financial support information was missing from the original version of this article. It is given below:

This work was supported by Scientific Research Projects Coordination Unit of Düzce University. Project number 2017.05.04.544.

Open Access This article is distributed under the terms of the Creative Commons Attribution 4.0 International License (http:// creativecommons.org/licenses/by/4.0/), which permits unrestricted use, distribution, and reproduction in any medium, provided you give appropriate credit to the original author(s) and the source, provide a link to the Creative Commons license, and indicate if changes were made.

Publisher's Note Springer Nature remains neutral with regard to jurisdictional claims in published maps and institutional affiliations.

The original article can be found online at https://doi.org/10.1007/s40065-018-0201-0.

F. Usta $(\bowtie) \cdot$ H. Budak · T. Tunç · M. Z. Sarikaya

Department of Mathematics, Faculty of Science and Arts, Düzce University, Düzce, Turkey

E-mail: fuatusta@duzce.edu.tr

H. Budak

E-mail: hsyn.budak@gmail.com

T. Tunç

E-mail: tubatunc03@gmail.com

M. Z. Sarikaya

E-mail: sarikayamz@gmail.com 